Scientia Militaria vol 40, no 3, 2012, pp.429-471. doi: 10.5787/40-3-1036

\title{
Resurrection of the Marine Capability in the South African Navy: The Maritime Reaction Squadron
}

\author{
Calvin Manganyi ${ }^{\bullet}$
}

\begin{abstract}
The disbandment of the Marine Branch of the South African Navy (SAN) in 1990 following the end of the Border War, culminated in the loss of a marine capability geared to operate in an amphibious theatre. Budget cuts and the need to acquire new warships necessitated the disbandment of the marines. Following the country's reacceptance into the international community in 1994, the newly formed South African National Defence Force (SANDF) found itself within a very short space of time involved in peace missions in the troubled Great Lakes region and elsewhere. The SAN, as part of the SANDF, was also drawn into peace missions. Members of the Protection Force and the Operational Diving Teams (ODTs) participated in peace missions and other exercises that demanded the marine capability. With the realisation that South Africa has been, and still is, involved in peace missions, the Chief of the SAN (C Navy) decided to resurrect such capability through the creation of the Maritime Reaction Squadron (MRS) in 2006. The MRS, however, does not mirror the defunct marines because it incorporates other elements such as divers who were absent in the first two marines. Even though it faces challenges, the MRS has conducted, and continues to conduct, various exercises and operations in support of South Africa's foreign policy efforts.
\end{abstract}

Keywords: marines, South African naval diplomacy, SAN, MRS, Operational Diving Division, Operational Boat Division, Reaction Force Division

- Calvin Manganyi is a lecturer at the Department of Political Science (Mil), Faculty of Military Science, Stellenbosch University. 


\section{Introduction}

Marine forces, hereafter "marines", are some of the specialised armed forces in the world. Marines imbue navies with a marine capability, which may be defined as the ability of amphibious forces to conduct operations such as amphibious engagement, crisis response, amphibious raids, amphibious assaults, amphibious withdrawals and amphibious demonstrations at sea. ${ }^{1}$ Navies world-wide have established marines in order to gain dominance in the amphibious theatre of engagement during both peace and war. Throughout the years, marines were used in various operations. For instance, the United States Marine Corps (USMC), which is perhaps the world's largest marine force, participated in various amphibious operations such as Operation Desert Storm in 1991 in Iraq and Operation Restore Democracy in Haiti in 1998 to name but a few. ${ }^{2}$ In the $21^{\text {st }}$ century, marines are mainly used for constabulary functions such as anti-piracy, humanitarian assistance and disaster relief operations. ${ }^{3}$ The recent scourge of piracy off the coast of the Horn of Africa has resulted in several countries sending their marines as efforts to eradicate the problem.

The SAN has established and disbanded two types of marines between 1951 and 1990. More recently, new marines were established in the form of the MRS, which signify the resurrection of the marine capability in the SAN. The roles and functions of the MRS include the following:

- conducting inland water patrols, on lakes, waterways and rivers;

- conducting search and seizure operations during inland water patrols;

- executing boarding operations in national and international waters;

- providing deployable small craft, both inshore in the littoral and on inland waters in a defensive role;

- protecting SAN and visiting vessels in national and international harbours and anchorages;

- $\quad$ conducting ship-to-shore and shore-to-shore operations; ${ }^{4}$ 
- ferrying limited personnel in the inshore littoral and the inland waters; and

- providing operational small craft support services to other state departments.

This article emanates from the research conducted for a thesis, "South African naval diplomacy since 1994", in fulfilment of the requirements for the degree of Master of Military Science at Stellenbosch University.

The aim of this article is to analyse the MRS as the resurrected marine capability of the SAN. The article commences by offering an overview of South African marine capability. It then contextualises the need for the marines in the post-1994 settlement, followed by a description of various elements of the MRS, namely the Operational Boat Division (OBD), the Operational Diving Division (ODD), the Reaction Force Division (RFD) and the Maintenance Division. The article also focuses on various exercises and operational deployments conducted by the MRS since its formation with the view of highlighting successes and challenges.

\section{An Overview of South African Marine Capability}

Although a marine capability in the SAN dates back to 1951, it lacks continuous or unbroken history. South Africa has established three various types of marines since the formation of the Union Defence Force (UDF) in 1912. The first marines came to existence on 1 July 1951 in the form of the South African Corps of Marines, ${ }^{5}$ with Brigadier P. de Waal appointed Naval and Marine Chief of Staff. ${ }^{6}$ It consisted of eight permanent force coast regiments, a marine technical centre, one training unit, seven citizen force coast regiments, Walvis Bay Heavy Battery, two light anti-aircraft regiments, four anti-aircraft batteries, three radar companies and the marine branch of the Naval and Marine Gymnasium. ${ }^{7}$ Unfortunately, the South African Corps of Marines existed for only five years. The main reason for its disbandment included the sophistication of Russian battleships equipped with guided missile launchers during the Cold War (from the 1940s to 1990). These ships rendered counter-bombardment forces obsolete; and this reality coupled with the fact that the South African Corps of Marines was perceived as a gratuitous expense led to the decision to discard coastal 
artillery. ${ }^{8}$ Subsequently, the South African Corps of Marines was disbanded on 1 October $1955 .^{9}$

During the Cold War when African states became the battleground for proxy wars between two opposing blocks led by the United States of America (USA) and the Union of Soviet Socialist Republics, the SAN lacked a marine capability. ${ }^{10}$ As the Cold War intensified, South Africa, particularly the South African Defence Force, fought the Border War between 1966 and 1989 in Namibia (then South West Africa) and Angola. ${ }^{11}$ Suddenly, the need to resuscitate a marine capability to patrol the coast, rivers and lakes as part of the counter-insurgency strategy became apparent. ${ }^{12}$ Subsequently, the second marines designated as 1 Marine Brigade was created in $1979 .{ }^{13}$ Their main purpose was to enable the SAN to participate in counter-insurgency operations, ${ }^{14}$ as well as the protection of naval bases and facilities. ${ }^{15}$ Initially, a brigade size force (hence 1 Marine Brigade) capable of sea-borne operations was envisaged. However, budget cuts and great emphasis on landward counter-insurgency strategy, prevented the marines from reaching the intended size. Instead, the marines never exceeded two battalions, hence the Marine Battalion rather than the Marine Brigade.

The Marine Battalion was later designated as the Marine Branch. ${ }^{16}$ Captain (SAN) I. Little laid the foundation leading to its establishment. In fact, he was disappointed when he was not appointed to lead the Marine Branch forward. The basic training of the marines commenced at SAS Saldanha under the leadership of Captain (SAN) D. Shelver in 1979. ${ }^{17}$ They continued with advanced training at the Infantry Battalion in Grahamstown from 1979 onwards. The marines participated in various theatres of operations during the Border War such as Katima Mulilo in South West Africa and Operation Daisy in November 1981 in the central part of Southern Angola. They also executed Exercise Magersfontein in Walvis Bay in September and October of 1988 when the SAN demonstrated its deterrence capabilities as part of coercive South African naval diplomacy or gunboat diplomacy. ${ }^{18}$ However, the end of the Border War coupled with the political developments in South Africa rendered the marines redundant. Budgetary cuts made decision-makers disband the marines in $1990^{19}$ and the SAN retrenched 2258 members of its personnel. ${ }^{20}$ The decision, which 
then seemed rational, was revisited in the post-1994 settlement following the country's transition to democracy.

\section{The Need for Marines in the Post-1994 South Africa}

Following the disbandment of the marines, South Africa was left with no forces geared for marine-type operations. The country's reacceptance into the international community following the 1994 democratic elections coincided with several ferocious intra-state conflicts ravaging several parts of Africa. ${ }^{21}$ Subsequently, all major policy documents of the country reflected the need to contribute to eradicating African conflicts. In order to play a positive role in conflicts, South Africa entered into a peace mission discourse, which later featured in various policy documents. International peace missions are regarded as secondary functions of the SANDF as contained in major South African policy documents such as the White Paper on Defence and the White Paper on South African Participation in International Peace Missions. ${ }^{22}$

Since 1997, the country has been instrumental in brokering African peace. It brokered peace in Angola, Burundi, Lesotho, Kenya, Mozambique, Sierra Leone, Sudan and Zimbabwe. Additionally, South African peacekeepers deployed to countries such as Burundi, the Democratic Republic of Congo (DRC), Comoros, Eritrea-Ethiopia, the Central African Republic and Sudan. ${ }^{23}$ Evidently, South Africa began taking centre stage in conflict resolution and management in the region beginning with mediation efforts in several countries. In 1997, the then South African President, Nelson Mandela, mediated between Mobutu Sese Seko, then President of Zaire, and Laurent Kabila. ${ }^{24}$ Initially, Mandela sought to convince Mobutu to form a coalition government with Kabila. ${ }^{25}$ Later in May 1997, South Africa initiated Operation White Dove during the Great Lakes peace process. ${ }^{26}$ The operation was part of South African naval diplomacy and involved the use of the now decommissioned SAS Outeniqua, docked at Pointe Noire in the DRC, as a feasible non-aligned platform for peace negotiations. ${ }^{27}$

The South African government utilised SAS Outeniqua as the venue for peace talks at sea, off the coast of Zaire, away from the hostilities. ${ }^{28}$ The talks resulted in what became known as the Outeniqua Agreement or 
Accord, named after the ship, which sought Laurent Kabila succeeding Mobutu Sese Seko as the President of Zaire, and eventually changing the country's name to the DRC. ${ }^{29}$ Thabo Mbeki, then Deputy President of South Africa, congratulated the SAN for "discharging its responsibilities with great distinction and loyalty to the national cause”30 during the 1997 negotiations in the DRC. He also stressed that the SAN is a significant partner in the realisation of the African Renaissance. The Outeniqua Agreement proved difficult to implement leading to the SANDF being involved in the peace process.

Given the dynamics of the Great Lakes and the fact that the SANDF did not have marine-style trained forces, the SAN was soon called to assist. $^{31}$ Unfortunately, its contribution was limited by the lack of the disbanded marine capability. In fact, some scholars such as Heitman argued that "[t]he Navy should further consider establishing a small marine branch to handle the very specialised and highly demanding role of amphibious raids and larger-scale beach-landing operations" ${ }^{32}$ needed for the African continent. It seems the recommendations failed to resonate, at the time, with the leadership and the reasons for that, whether budgetary or otherwise, are unclear. Nonetheless, it was apparent that Africa was in a state of flux and that the SANDF would commence playing a major role in conflict resolution and management.

When the Burundi conflict emerged after rebels attacked Bujumbura, Mandela became the leader of the Arusha Peace Process in December 1999. South Africa commenced deploying a contingent to protect negotiators during the process. Following the institutionalisation of the United Nations Operations in Burundi (ONUB), the SANDF deployed 1264 personnel of whom 44 were members from the SAN. The maritime contingent was responsible for waterborne operations in Lake Tanganyika covering about $133 \mathrm{~km}$. The SAN used harbour patrol boats (HPBs), operated by members of the Protection Force, to conduct operations. ${ }^{33}$ The employment of these elements illustrated the need for naval forces geared for operating in fresh water as well as amphibious theatres. However, that capability diminished with the disbandment of the Marine Branch. In an interview with Navy News in 2005, Vice-Admiral J. Mudimu, C Navy, stated he was "considering the possibility of reconstituting the '(m)arines'”34 to be able to deal with African challenges in the $21^{\text {st }}$ century. Hence, the MRS came to 
existence as an effort to resurrect the marine capability a year after C Navy's statement.

\section{Resurrection of Marines: The Maritime Reaction Squadron}

The SAN established the MRS on 1 September 2006, ${ }^{35}$ which marked the resurrection of the marine capability in the SAN as well as the SANDF. However, the MRS was only commissioned on 9 December $2008 .{ }^{36}$ It is commanded by a Captain (SAN) and the Officer Commanding in 2008, Captain (SAN) S.F. Petersen, is a former marine who served in the Marine Branch before its disbandment. Headquartered at Scala, formerly used by marines until $1990,{ }^{37}$ the MRS is an official unit of the SAN with the aim of imbuing the SANDF with peacekeeping capabilities in Africa's freshwater lakes and rivers, as well as amphibious operations, ${ }^{38}$ boarding operations at sea, humanitarian operations and disaster relief. ${ }^{39}$ According to the maritime doctrine of the SAN (SANGP 100), which guides naval forces in pursuit of both national and military objectives in support of South Africa's foreign policy, there are ten main tasks of the MRS. Most of the tasks have been mentioned. Other tasks include establishing a Forward Deployable Base (FDB), procured as part of Project Xena (discussed later), from which operations may be conducted. ${ }^{40}$ These are the same tasks contained in the Concept of Operations (CoO) of the MRS approved in 2007, a year after its official establishment and a year prior to its official commissioning, as well as other documents such as SANGP 1, SANGP 15 and SANGP 40 outlining the different roles of the SAN. ${ }^{41}$

The CoO, however, is out of date because the MRS is currently conducting operations, which were not initially envisioned such as antipiracy operations. Subsequently, the MRS is in a process of revising and updating the $\mathrm{CoO}$, but its approval date is yet to be determined. ${ }^{42}$ The contents of the new $\mathrm{CoO}$ remain classified, but it seems it will be more suited for the current operational environment. ${ }^{43}$ One can postulate that anti-piracy operations will feature prominently in the new CoO. The most pertinent argument that transpired during some interviews with anonymous participants includes the fact that the current $\mathrm{CoO}$ lacks provision for Force Protection and Reaction Teams to deploy with each and every sea-going ship at any given time. This renders the ships vulnerable, especially in the current environment where piracy at sea is rife. Currently, only divers 
deploy with sea-going ships at all times. Another argument was that members of the MRS should be highly trained in order to withdraw special forces elements operating with them. Special forces are strategic assets, which should only be employed in severe circumstances such as anti-piracy. Regardless of the revealed issues, it is clear that the MRS is more than a marine force because it consists of four interconnected components, namely OBD, ODD, RFD and the Maintenance Division. ${ }^{44}$

\section{Operational Boat Division}

The OBD dates back to the establishment of the Operational Boat Squadron in 2005. Prior to the establishment of the Operational Boat Squadron, HPBs or Namacurras and similar small craft resorted under Protection Force units at Simon's Town and Naval Station Durban. ${ }^{45}$ Some HPBs were attached to the Naval College Gordon's Bay and the President Jetty at the Naval Gymnasium, SAS Saldanha. Owing to the need for operational boat crews and protection contingents at the Great Lakes and other areas pursuing South Africa's interests, Vice-Admiral Mudimu, commissioned the Operational Boat Squadron. The decision was to ensure that the SAN contributes meaningfully to South Africa's commitments at the Great Lakes. ${ }^{46}$ Members of the squadron served in Burundi and other areas on the continent as well as when requested to assist other departments and the South African Police Service (SAPS). Three HPBs were sent to the Great Lakes to enhance security on Lake Tanganyika as part of the SAN contribution to the African Union Mission in Burundi. ${ }^{47}$ The Operational Boat Squadron was instrumental in riverine operations from 2003 to 2007 as part of the SANDF contingent deployed in Burundi. ${ }^{48}$

Following the formation of the MRS, the Operational Boat Squadron was upgraded to the OBD and became part of the new unit. The Operational Boat Squadron, however, can be regarded as the genesis of the MRS. ${ }^{49}$ The SAN equipped the OBD with six Lima craft capable for beach-landing. Lima craft have a high speed of 29 knots, a range of 120 nautical miles, and a complement of $20 .^{50}$ The highly capable and versatile HPBs are also housed in the OBD. Lima craft can be launched from larger platforms such as SAS Drakensberg or the frigates. Similarly, to the Delta boats utilised by the Marine Branch, the Lima craft carries members of the RFD and ODD during operations. 


\section{Operational Diving Division}

In 1957, the SAN established its diving capability at the West Yard in Simon's Town, and the Diving Centre is still housed in this location as part of SAS Simonsberg. The amalgamation of ODTs East and West formed the ODD in the post-1994 settlement as part of the transformation processes in the SAN. The main functions of the ODTs include mine identification, mine avoidance, mine clearance, beachhead clearance, and explosive ordnance disposal. ${ }^{51}$ The divers regularly participate in DIVEX, which is a diving exercise envisioned in 1984 but which only came into existence in 1998. The aims of DIVEX include encouraging cohesion and refreshing diving theory and practice. ${ }^{52}$ Since 1994, the ODTs are instrumental in operations as part of South Africa's international maritime assistance. ${ }^{53}$ In 1996, SAN divers were called to assist after the capsizing of Ferry MV Bukoba on Lake Victoria. As part of naval cooperation between South Africa and other countries, the SAN divers, cooperating with Tanzanian divers, the Kenyan Navy and Tanzanian Railways recovered approximately 300 bodies. $^{54}$ The success of the operation led to the establishment of good defence diplomatic relations between the SANDF and the Tanzania People's Defence Force, and subsequently between the SAN and the Tanzanian Navy. ${ }^{55}$ It is for this reason that the ships of the SAN with members of the MRS patrol the Tanzanian coast during anti-piracy patrols (see Operation Copper).

Following its incorporation into the MRS, the ODD conducts domestic diving, search and rescue, deep diving at 54 meters, mine hunting and mine clearance, underwater device disposal, underwater salvaging, underwater drilling and welding, as well as other tasks. ${ }^{56}$ The equipment of the ODD includes a compression chamber for divers, six- and four-meter boats, as well as normal diving equipment. One of the major challenges facing the OOD is the four-meter boats, which have surpassed their 16-year life span in 2008. The only serviceable boats currently available are the sixmeter boats, which are difficult to transport using the four-wheel drives of the MRS. Despite these challenges, the ODD has completed several operations under the banner of the MRS. Some of the operations include deployment with the South African Air Force (SAAF), humanitarian relief in Mozambique, and assisting Tanzanian authorities as part of South African naval cooperation with the region as discussed later. 
In February 2010, the ODT on board SAS Protea was instrumental in salvaging the wreckage of a Pilatus PC-12 in Plettenberg Bay. The aircraft carrying a CEO of Italtile and eight other people crashed offshore near the Robberg Nature Reserve. ${ }^{57}$ Warrant Officer I. du Plessis led the ODT consisting of Petty Officer L. Lotter, Petty Officer K. Nsibande and Leading Seaman T. van der Walt. ${ }^{58}$ The ODT cooperated with SAPS divers. After surveys had been concluded utilising the shallow water route survey system, the ODT focused on salvaging the wreckage of the aircraft, while SAPS divers recovered human remains. The operation was concluded on 15 February 2010 and SAS Protea transported the recovered parts to Port Elizabeth for further inspection by the Civil Aviation Authority. ${ }^{59}$ In September 2011, ferry Spice Islander, capsized off Zanzibar and resulted in one of the catastrophic maritime disasters in history. The ferry capsized en route between Unguja and Pemba, which are two islands off the coast of Tanzania. It is suspected that more than 1000 voyagers were on board. ${ }^{60}$ Divers from the ODD managed to recover more than 200 bodies. ${ }^{61}$ It is some of these activities that make the ODD an important component of the MRS.

\section{Reaction Force Division}

The RFD is a brainchild of Vice-Admiral Mudimu and is crucial in projecting South Africa's foreign policy objectives with regard to bringing peace to the African continent as well as African waters. ${ }^{62}$ Although it is still in its infancy, the RFD should be understood as the main component of the marines that resurrected the capability lost when the Marine Branch was disbanded in 1990. Members of the RFD require both mental and physical strength as well as tenacity and fortitude to complete the rigorous selection process successfully. ${ }^{63}$ The RFD is an important component in anti-piracy operations, given the fact that South Africa recently illustrated its political will to eradicate the scourge of piracy, or at least prevent it from reaching Southern African waters. The RFD began as a Reaction Force in 2005 when former members of the Marine Branch trained 109 members from the Military Skills Development System intake. Their training commenced at the SAS Saldanha military area. Both RFD and OBD members receive similar training and are deployed to the various divisions in terms of need. ${ }^{64}$ These members also receive motorised infantry training, which make them versatile. They are able to serve in both infantry and amphibious roles. 
The Reaction Force, before the inception of the MRS in 2006, was commonly known as the MRS. This is, however, unsurprising given the fact that it is the core of the new unit. Prior to the establishment of the Reaction Force, the various divisions (now part of the MRS) existed as separate entities. They were only amalgamated to augment the capabilities of the Reaction Force by forming part of the MRS in 2006. The Reaction Force participated in various operations and has assisted other state departments. In June 2007, the Reaction Force together with the Operational Boat Squadron and SAS Tobie executed Operation Intexo assisting the Department of Environmental Affairs and Tourism. Operation Intexo was an anti-poaching operation aimed at preventing the extinction of one of the most endangered species, namely the Patagonian toothfish, and other maritime resources such as Cape rock lobster and perlemoen (abalone). The operation led to the incarceration of poachers off the Cape south coast. ${ }^{65}$ This illustrated that the creation of the RFD was a necessity as it proved its worth in assisting with the preservation of marine resources as part of the constabulary functions of the SAN.

Initially, the RFD consisted of a full-time company and a reserve company. Currently, it has three companies, which are rotated during operations. ${ }^{66}$ The companies comprise the leadership element, a motor section and rifle platoons. The leadership element, made up of selected junior officers in the SAN, receives its training from Infantry School in Oudtshoorn. Some of these officers studied at the Military Academy such as Lieutenant (SAN) P.P. Hlungwani, Sub-lieutenant D.S. Thukani and Sublieutenant R.O. Letsoalo (current platoon commander in the MRS). The designated mustering of some of the senior officers and junior officers is combat officer (marine), which was approved recently following years of the precarious use of combat officer (dry) operating in an amphibious environment. In 2009, the MRS was equipped with a deployable base and support equipment for operational deployments in Africa (see Project Xena) ${ }^{67}$ Between 2009 and 2010, several members of the SAN were deployed in peace missions in the DRC, Burundi, Sudan, the Central African Republic and Ethiopia. ${ }^{68}$ Some of these members were from the MRS as discussed later in the contribution on the Great Lakes region. Despite their contributions, RFD members face several challenges. The first challenge relates to the promotion of members. As a recently established unit headed by a captain (SAN), the promotion of combat officers (marine) 
is extremely slow. The second challenge, similar to those faced by other units of the SANDF, is ageing equipment. For instance, the boarding equipment used for fast roping is few years old and needs to be replaced. The third challenge is combat boots worn by the MRS. These boots are hard and suited for normal infantry soldiers that operate on land. ${ }^{69}$ They are certainly not conducive for the amphibious environment in which marines operate. The boots should be replaced by a softer design suited for both the amphibious environment as well as land. These challenges impact on the morale of the marines and require urgent resolution to enable the members to perform their duties diligently. The equipment also requires maintenance; hence, the creation of the maintenance division.

\section{Maintenance Division}

According to Captain (SAN) S.A. Malepe, Officer Commanding MRS, the Maintenance Division is a very recent development created out of need. It should be emphasised that it is not a fighting division, but a support one. It is charged with keeping all equipment of the MRS in optimum operational condition. The MRS is equipped with tantalising equipment procured under Project Xena (see next section), which needs special care. To fulfil this need, the SAN instituted the Maintenance Division. ${ }^{70}$ All equipment of the MRS including the boats of the OBD and ODD, as well as the vehicles and the FDB are maintained by the division.

\section{Project Xena}

Project Xena was first introduced to the public on 9 December 2008 when the MRS was commissioned. ${ }^{71}$ The project comprised the inshore and riverine equipment acquisition programme for the MRS aimed at providing a fully integrated, balanced and deployable system. ${ }^{72}$ Captain (SAN) N. Marais, project officer, explained that a rapid capability requires not only boats, but also a system that can sustain the boats. ${ }^{73}$ Consequently, it was necessary to acquire the boat system (including their trailers and a floating jetty), the FDB, command, control and communications, and transport. Project Xena was an R89-million project spanning from 2005 to 2009. ${ }^{74}$ The equipment acquired through the project enabled the MRS to participate meaningfully in exercises and operations. The MRS revealed its FDB on 25 November 2009 at the SAS Saldanha Sports Field. Members present 
included a delegation from the Ministry of Defence and Military Veterans, defence-related industries, senior officers from the SANDF as well as the media. ${ }^{75}$ The Base Camp Segment, dubbed "home away from home", is geared to accommodate 150 sailors. It is made of 33 six-meter containers and 22 (five by ten meter) tents. ${ }^{76}$ There are four sub-systems in the camp. The first comprises accommodation, gym, a dining hall, refrigerators and ablution facilities. The second makes provision for laundry, sewage, water purification, generators and armoury. The third comprises the administration tent, command control and communication and intelligence, the workshop tent and caisson walls. The last sub-system is composed of a floating jetty, riverine patrol boats and landing craft. ${ }^{77}$ It is worth noting that the camp is one of the best in the world. In fact, the USA and NATO forces use similar camps in Iraq and Afghanistan. ${ }^{78}$

While there may be lack of questions for acquiring the FDB; however, one may question the suitability of the system procured. The fact that other developed nations such as the USA are utilising a similar camp might not be the sole centripetal factor to incline South Africa towards a similar system. Other considerations are also very much important. For instance, the USA has unquestionable air and sealift capability to transport the FDB to any place where its forces are deployed. In the case of South Africa, there is currently a lack of sealift capability to transport the FDB to theatres of operations. It is undeniable that road transport in the form of heavy-load trucks may be used to transport the FDB as witnessed when the base was displayed at SAS Saldanha Sports Field. It should be noted that the SAN does not have the capability to effectively sealift the FDB. Simply put, can the SAN operate the FDB in places such as the South African islands of Marion and Prince Edward or any other place accessible by sea?

The current answer to the question is negative, unless a private sealift capability is chartered or assistance is rendered by friendly international forces possessing the capability, such as the USA or France. Following the decommissioning of SAS Outeniqua, the SAS Drakensberg remains the only support vessel, apart from the limited role of the aged SAS Protea, supporting seagoing ships and transporting other South African forces and departments. It seems that the problem might be solved in the future through Project Millennium aimed at acquiring sealift capabilities for the SANDF in the form of Mistral-class Landing Helicopter Dock. ${ }^{79}$ It should 
be noted; however, that Project Millennium seems to have lost momentum and currently its completion date remains unknown. Some are of the opinion that it might only be completed by the year 2025 or $20300^{80}$ Despite these challenges, the SAN has managed to deploy the MRS with its new equipment, excluding the FDB in most instances, to various multi-national and national exercises as well as operations, as discussed in the next section.

\section{Multi-national and National Exercises}

Multi-national exercises, particularly naval exercises, fall within the domain of naval presence, which is benevolent in nature. ${ }^{81}$ These exercises are aimed at confidence building, encouraging naval interactions and cementing ties as well as creating and gaining influence within a theatre of operation. ${ }^{82}$ Since its inception, the MRS has conducted various exercises in order to prepare for operations. Some of the exercises include Shared Accord, Golfinho, Good Hope, and Ndlovu.

\section{Exercise Shared Accord}

Shared Accord exercises are initiatives of the USA Africa Command (US AFRICOM) aimed at assisting African armed forces to deal with current African challenges. They mainly focus on rural upliftment on the African continent. ${ }^{83}$ Each year, since Shared Accord's inception, an exercise is held with one African country. The USA and Niger forces held Exercise Shared Accord 2006, ${ }^{84}$ which was aimed at interoperability between the two forces in March 2006. ${ }^{85}$ The following year, the USA and Senegalese forces held Exercise Shared Accord 2007, which was concluded on 30 June 2007. ${ }^{86}$ The USA and Ghanaian forces held Exercise Shared Accord 2008 aimed at sharpening humanitarian relief capabilities. ${ }^{87}$ In June 2009, the USA and Beninese forces held Exercise Shared Accord 2009 aimed at conducting infantry and staff training. The success of the exercise was followed by another one with Mozambique in 2010. Exercise Shared Accord 2010 was held in the Moamba district, in the southern Mozambican province of Maputo in August 2010. ${ }^{88}$

The following year, South Africa participated in Exercise Shared Accord 2011, which took place in Port Elizabeth and Grahamstown from 18 July to 2 August 2011. Members of the MRS were part of the SAN 
contingent. Before the commencement of the exercise (between 30 May and 13 July 2011), members of the MRS conducted combat readiness training at the SAS Saldanha military area. The training included patrol, navigation, night navigation, section platoon attacks, a $10-\mathrm{km}$ route march and pyrotechnic firing using live ammunition. The aim of Exercise Shared Accord 2011 was to provide comprehensive training between the armed forces of South Africa and the USA, as well as to build interoperability and mutual understanding between the two forces. ${ }^{89}$ Rear-Admiral H. Teuteberg was the exercise commander. Elements from the South African Army (SA Army), SAAF, South African Military Health Services (SAMHS) and the SAN participated in the exercise. The USMC contingent exercised with the Grahamstown-based 6 South African Infantry Battalion (6 SAI) augmented by RFD members during the exercise. ${ }^{90}$ The RFD played various roles including anti-piracy demonstrations, beach-landing, section attacks and counter attacks. The USMC contingent provided fire support during the exercise. $^{91}$ The SAAF and SAN conducted exercises at sea along the southern coast, and members of the MRS were also present conducting antipiracy exercises such as boarding operations and protection of vessels against pirates. At the closing ceremony, the exercise commander stated that the exercise had been a success. ${ }^{92}$ The satisfaction of the exercise commander and the personal experiences of some of the interviewed officers participating in the exercise illustrated that the MRS was successful in its main roles both at sea and on land. During deployment at sea, the RFD protected naval vessels and conducted boarding operations to suspected ships as part of the exercise. These operations were executed successfully and provided the members with training in the execution of similar operations under Operation Copper (to be discussed later).

\section{Exercise Golfinho}

Exercise Golfinho was a multi-national exercise involving 11 Southern African Development Community (SADC) countries, and was held in September 2009. These members were Angola, Botswana, the DRC, Lesotho, Malawi, Mozambique, Namibia, Swaziland, Tanzania, Zambia, Zimbabwe and South Africa. ${ }^{93}$ The aim of the exercise was to test multidimensional peace support operations readiness of SADC forces including the police and civilian elements in accordance with the African Union roadmap pertaining to the establishment of the SADC African 
Standby Force. ${ }^{94}$ Its objectives included exercising inter-agency liaison with international, governmental and non-governmental organisations; practicing command and staff liaison in multi-national headquarters; examining information-gathering capabilities; exercising humanitarian relief operations; exercising mission sustenance procedures; and testing media handling capabilities for commanders and staff. ${ }^{95}$

Exercise Golfinho occurred between 1 and 26 September 2009 at Lohatla, ${ }^{96}$ the SANDF Combat Training Centre located in the Northern Cape, and Walvis Bay. ${ }^{97}$ The landward force was based at Lohatla, while the seaward force was at Walvis Bay. ${ }^{98}$ The seaward force was composed of sea, land and air elements. Two frigates (SAS Amatola and SAS Mendi each with members of the MRS on board), a submarine, an offshore patrol vessel, an inshore patrol vessel, two police "waterwing" craft, two Limaclass landing craft, three HPBs, an ODT and elements from 4 Special Forces Regiment comprised the sea elements. The FDB of the MRS was not used during the deployment, ${ }^{99}$ because the SAN, as mentioned earlier, lacks sealift capability to carry large numbers of forces and vast amounts of equipment to the theatre of operations. Land elements encompassed one MRS platoon, one platoon of Namibian marines, one platoon of Angolan marines and elements from 5 Special Forces Regiment. The air elements consisted of two Super Lynx helicopters on board the frigates, a maritime patrol aircraft and an Oryx from the SAAF. ${ }^{100}$

Captain (SAN) Petersen, then Officer Commanding MRS, ${ }^{101}$ was appointed Maritime Task Force Commander, responsible for commanding all forces participating in Walvis Bay. He reported to SADC African Standby Force commander, Brigadier General L.R. Smith based at Lohatla. ${ }^{102}$ During the exercise, delegates ranging from defence ministers to high-ranking officials from the participating countries' defence forces visited Lohatla and Walvis Bay. ${ }^{103}$ The SAN and members of the MRS have contributed both at sea and on land during the exercise. The MRS together with the other marines from Angola, Namibia and elements of 5 Special Forces was responsible for boarding operations, beach-landing operations and protection of vessels at sea and the harbours. It seems that MRS contently plays an important role in boarding operations. In addition, the MRS is interoperable with other marines from several SADC countries as illustrated in the exercise. 


\section{Good Hope Exercises}

Good Hope exercises are biennial, joint and bi-national naval and air exercises between Germany and South Africa, which began after 1994. Exercise Good Hope II, held from 20 February to 10 March 2006 by the German and South African naval and air forces, was aimed at improving combat readiness of the two countries. ${ }^{104}$ Exercise Good Hope III was held between 18 February and 18 March 2008. ${ }^{105}$ Between 15 February and 15 March 2010, the two states held Good Hope IV in South African waters, the Cape waters in particular. The objectives of Good Hope IV were to enhance and maintain defence capabilities of the two countries, and to enhance interoperability, mutual trust, respect and cooperation between Germany and South Africa. ${ }^{106}$ During this exercise, members of the MRS conducted anti-piracy demonstrations engaging aggressive pirates at sea. ${ }^{107}$ The actions demonstrated by the MRS in particular, and the SAN in general, reaffirmed the assertion that South Africa was ready for the 2010 FIFA World Cup. The exercise also gave an opportunity for the MRS to test its capabilities before the June and July 2010 deployments (see Operation Kgwele).

The success of the 2010 exercise was followed by another one. This was Good Hope V held between 5 and 23 March 2012 in Durban, Simon's Town and the eastern and southern coast of South Africa. Similar to prior exercises, Good Hope V was aimed at building mutual understanding and interoperability between the two countries. In addition, it was intended to enhance anti-piracy capabilities of the SAN in order to deal with piracy off the East African coast under Operation Copper. ${ }^{108}$ SAS Isandlwana, SAS Amatola, a Super Lynx helicopter, elements of the MRS and special forces represented South Africa. The special forces and members of the MRS have illustrated their capabilities and precision during the demonstration of a tactical movement aimed at deterring pirates and protecting a vessel. ${ }^{109}$ These skills are direly needed as part of the deterrence capabilities of the SAN to eradicate piracy off the African coast. In addition to multi-national exercises, the SAN participate in national exercises. One of these exercises is briefly outlined below. 


\section{Exercise Ndlovu}

Three years of scrupulous planning and dedication culminated in Exercise Ndlovu held in November 2011. Exercise Ndlovu was directed by Brigadier General Liebenberg headquartered in Kimberley. The exercise was aimed at assuring the country that the SANDF has defence and reaction capabilities to protect South Africa's sovereignty against any external attack from land, air or sea. ${ }^{110}$ It was a combined exercise including the SA Army, the SAAF, the SAMHS and the SAN. Based on the scenario of the exercise, the landward forces encompassing elements of the SA Army, SAAF and SAMHS, covered the interior, while the seaward forces led by the SAN supported by the elements of the SAAF and SAMHS provided coastal protection. ${ }^{111}$ The landward forces demonstrated their capabilities in Bloemfontein, Potchefstroom, Lohatla and the Vastrap training area in Upington.

The seaward forces mobilised in Saldanha Bay. ${ }^{112}$ The SAN deployed SAS Drakensberg (a combat support vessel), SAS Charlotte Maxeke (one of the three SAN submarines), SAS Umzimkulu (mine counter-measures vessel), and the MRS. SAS Charlotte Maxeke demonstrated naval coercion using submarine capability. ${ }^{113}$ The SAN submarines are South Africa's ultimate strategic weapon. ${ }^{114}$ The advantages of submarines enabling them to be instrumental as strategic weapons suited for gunboat diplomacy and naval warfare include stealth, mobility, firepower, endurance, survivability and effectiveness. ${ }^{115}$ The SAN submarines have performed well when engaging with other forces during various exercises, particularly off the Cape south coast.

Members of the RFD boarded SAS Drakensberg from the fore flight deck as part of the fast-roping demonstration, while SAS Umzimkulu spotted "pirates" and responded with an anti-piracy attack on the "pirate" ship led by RFD members armed with R5 rifles. At the completion of the exercise, Brigadier General Liebenberg reported to the Chief of Joint Operations, Lieutenant General D. Mgwebi that it was a success and that junior officers have illustrated decisiveness, command and control. ${ }^{116}$ These are the same attributes that make these officers valuable in various exercises and operations. It is clear that the MRS is an important component for the SAN and the SANDF. Although it may be considered an infant, the MRS has 
illustrated an unrivalled capability, at least in the African context, in demonstrating boarding operations and protecting vessels as well as performing other amphibious duties during the various exercises. It is this capability that makes the MRS a necessity in peace missions such as in the Great Lakes region and elsewhere.

\section{Contributions in the Great Lakes Region}

Prior to the formation of the MRS, the SAN contributed elements such as the Operational Boat Squadron and members of the Protection Force to the SANDF peacekeeping missions in the Great Lakes region as previously stated. Following its formation in 2006, the MRS deployed various elements to the Great Lakes region. ${ }^{117}$ In 2007, during Operation Curriculum, initiated as a special task force in Burundi under the banner of the African Union, the MRS deployed members to that country. ${ }^{118}$ Sublieutenant D.S. Thukani (then Able Seaman) deployed with 39 other members of the RFD in Burundi. The initial role of these members was to protect the very important people (VIPs) returning from exile to engage in the negotiating process. ${ }^{119}$ This deployment included other members of the SANDF, which played various roles. ${ }^{120}$ While RFD members were at the demobilisation centre at De Brug, Bloemfontein, preparing for deployment to Burundi, they faced a major setback when it became apparent that they were not trained for VIP protection. At the time of operational planning for the mission, it seems the responsible planners omitted to realise that the types of activities the MRS can perform, excluded VIP protection.

Certainly, the SAN has members that can perform VIP protection duties; ${ }^{121}$ regrettably, the MRS members do not perform such operations. ${ }^{122}$ While at De Brug, these members were almost withdrawn and returned to their base in Simon's Town. Fortunately, they were kept as part of the contingent. Their evitable failure to deploy to Burundi due to omission would not only have had serious ramifications for the MRS, but for the SAN as well. It is postulated that the MRS would have been viewed as a failure even though the planners were responsible for the omission. This is based on the understanding that the rationale for the resurrection of the third marines was their future role in conflict resolution and management, particularly peace missions. 
The ability of decision-makers in the SANDF, Chief of Joint Operations and his staff in particular, to adapt to changing circumstances has saved the MRS embarrassment. Subsequently, other duties were allocated for the members. The main duty included protecting the houses in which the returning VIP members were housed instead of protecting the members themselves. Other roles encompassed guard duties. ${ }^{123}$ The challenges experienced by the RFD members included the lack of adequate training, as the unit was still an infant, which caused anxiety. A contributing factor to this was the fact that many of the members were on their first deployment. The situation has changed drastically since that deployment of the RFD. Members have since underwent various training programmes both in the SAN, Infantry School and other training areas in South Africa and abroad, as well as multinational exercises with other navies and national exercises with other elements of the SANDF (as discussed) and the SAPS. ${ }^{124}$

Following the commissioning of the MRS, its members continued their deployments to various areas in the Great Lakes region. On 15 December 2008, 19 MRS members deployed to the DRC for six months as part of the United Nations Mission in the Democratic Republic of Congo. Their main role was to guard the air force base of the United Nations in the Kamina and Katanga provinces. Their duties included patrolling and guarding the unit as well as providing access control. ${ }^{125}$ A year later, in May 2009, the members were relieved by other members of the MRS. ${ }^{126}$ From 26 November 2010 to 26 May 2011, the MRS deployed members to the DRC under the United Nations Organisation's stabilisation mission in the DRC (MONUSCO) as part of the SANDF's Operation Mistral. Sublieutenant Letsoalo deployed as the protection element commander of the 18 members of MRS contingent formed by the RFD and ODD deployed in the eastern DRC at Goma, near Lake Kivu.

The main duty of the members was to protect South African aviation elements, while the Indian contingent protected those of MONUSCO. ${ }^{127}$ Other responsibilities included protecting civilians, humanitarian workers and human rights defenders under threat of physical violence from the belligerents at Goma, near Lake Kivu and surrounding areas. ${ }^{128}$ During the deployment, no serious combat action was experienced, although uncertainty was rife. All 19 members deployed returned home safe and 
sound. The only challenges experienced by the members were disciplinerelated issues due to boredom. ${ }^{129}$ Despite its contributions to the Great Lakes and other areas and missions, the major weakness of the MRS remains its equipment. Most of the equipment utilised was ageing and some had surpassed their life span, such as the boats mentioned earlier. In addition, other equipment was lacking. Failure to address the challenges with regard to equipment may result in the MRS unable to discharge its duties during operations.

\section{Operation Kgwele}

The Commander-in-Chief, President Jacob Zuma, has instructed the SANDF to assist the SAPS in securing the country during the 2010 FIFA World Cup. The World Cup was one of the biggest sporting events in the sporting history of South Africa that attracted people from all walks of life. The country and the world were excited knowing that it was for the first time the event was hosted on the African continent. An event such as the 2010 World Cup does not only bring excitement and opportunities, but also threats or potential threats. In order to deter these threats, the SANDF initiated Operation Kgwele following the instruction of the President. ${ }^{130}$ Brigadier General J. Liebenberg was the joint task force commander for the operation and he emphasised the importance of amalgamating the country's resources to ensure safety and security. ${ }^{131}$ Dr Lindiwe Sisulu, then Minister of Defence and Military Veterans, visited the National Joint Operations Centre (NATJOC) at the SAAF Headquarters in Pretoria on 9 June 2010 to evaluate combat readiness with regard to Operation Kgwele. Brigadier General Liebenberg assured the Minister that the SANDF was geared and ready for the operation. ${ }^{132}$ He also provided a concise presentation to the Deputy President, Kgalema Montlanthe, during his visit to the NATJOC on 9 July 2010. ${ }^{133}$

During the operation, the SAN's main task was to ensure the safety of the three coastal host cities: Durban, Port Elizabeth and Cape Town. ${ }^{134}$ Each of the harbours in the three cities was provided with one ship and its crew in order to react to the challenges should a need arise. In addition, 78 members were deployed in each harbour comprising:

- an ODT; 
- 22 members, for underwater demolitions;

- $\quad$ an MRS platoon from RFD;

- 38 members, for security and harbour protection; ${ }^{135}$

- a medical team;

- a communications team to ensure communication between the ships;

- a protection platoon from the Protection Force for harbour protection and security;

- an HPB to conduct harbour and coastal patrols;

- $\quad$ survey motor boats to conduct underwater surveys;

- picture processing elements for underwater security and assessment; and

- $\quad$ an underwater sabotage device disposal team for bomb disposal by ODT. ${ }^{136}$

The SAN commenced deploying its members for the operation as early as 24 May 2010, ${ }^{137}$ which was combined with Operation Corona aimed at deploying over 3000 soldiers for border control by $2014 .{ }^{138}$ The elements of the SAN participating in Operation Kgwele included frigates, submarines, a hydrographic survey ship, the MRS, two strike craft, two counter-measure vessels, and chemical, biological, radiation, nuclear and explosives teams. SAS Amatola was deployed in Port Elizabeth, while SAS Spioenkop and SAS Mendi were deployed in Durban and Cape Town respectively. ${ }^{139}$ SAS Protea, under the leadership of Captain (SAN) T. Stokes, ${ }^{140}$ was deployed in Port Elizabeth for the duration of the tournament to ensure the safety of the harbour and the stadium. ${ }^{141}$ A hydrographic survey team equipped with sonar motor boats conducted sonar detection and sent the information to be processed on board the SAS Protea. ${ }^{142}$ SAS Umkomaas and SAS Umzimkulu conducted underwater security in Durban and Cape Town harbours. ${ }^{143}$ Three platoons (one per stadium) of the MRS 
were deployed as observers around the stadia and were ready for rapid deployment anywhere needed. ${ }^{144}$ The ODT was responsible for protecting the harbours from underwater threats, while the RFD platoons played multidimensional roles. They protected the harbours and also served as security around the venues at the stadia. In Cape Town, the MRS utilised the FDB. ${ }^{145}$ The three venues in which the MRS was deployed did not experience any threats during the duration of the World Cup. Subsequently, it can be stated that the MRS contributed greatly to the success of Operation Kgwele by providing security and deterrence in the various areas of deployment during 2010. This success has illustrated that the MRS is an important asset in dealing with maritime challenges facing Southern Africa, particularly piracy in the Mozambique Channel and off the coast of Tanzania, provided a political will exists.

\section{Dealing with Piracy: South Africa, Tanzania and Mozambique Maritime Security Cooperation}

Piracy has been a problem facing the world for many years. Recently, the coast along the Horn of Africa has been one of the areas affected by piracy. Yet, African states seemed to lack the political will to devise strategies to deal with piracy. But what is piracy? "Piracy" and "armed robbery" are defined by the International Maritime Bureau (IMB) of the International Chamber of Commerce (ICC) as "an act of boarding or attempting to board any ship with the apparent intent to commit theft or any other crime and with the apparent intent or capability to use force in the furtherance of that act". ${ }^{146}$ Article 101 of the 1982 United Nations Convention on the Law of the Sea (UNCLOS) defines piracy as illegal activities committed for private gains by the crew or passengers of a ship, against another ship, persons or property on board such a ship. ${ }^{147}$ Over the past two decades, piracy became blatant and more vicious with the utilisation of handheld military hardware such as AK-47s and rocket-propelled grenades (RPGs). ${ }^{148}$ McNicholas highlights recent cases from the hijackings of the American transport barges Hawk and Falcon, to the attack of the United Arab freighter IBN Younos off the coast of Somalia en route from South Africa to Dubai. ${ }^{149}$ Following these and other similar incidents, piracy became an issue of international concern. In fact, African waters are some of the world's dangerous waters in terms of piracy. ${ }^{150}$ Off the African coast, Potgieter states that piracy is a serious concern, which needs immediate attention. ${ }^{151}$ 
Evidently, during various meetings and conferences such as the third Sea Power for Africa Symposium held in 2009, piracy topped the agenda and the SAN and its African counterparts have appreciated that piracy need to be eradicated. ${ }^{152}$ These sentiments are shared by analysts such as Heitman, who states that the expanding role of South Africa as a regional power in the quest for international peace and security would likely extend the role of the SAN to anti-piracy operations to enhance maritime security in Southern Africa. ${ }^{153}$ However, it seems that the political will on the part of African decision-makers was lacking with regard to conducting anti-piracy operations. Kruger argues that there was increasing pressure on South Africa to join anti-piracy operations off the east African coast. In addition, the European Union requested the country to join the task force on antipiracy. ${ }^{154}$ The reasons for the reluctance then remained open-ended. It can be postulated that it is perhaps due to a lack of resources as many African states have relatively small, regrettably insignificant navies, which rely on South Africa for assistance in the maritime domain. ${ }^{155}$ These are sentiments amongst flag officers and other high-ranking officers from various navies around the world as reflected during the third Indian Ocean Naval Symposium (IONS) held at the Cape Town International Convention Centre from 10 to 13 April 2012. ${ }^{156}$ The delegates at IONS 2012 believe that the SAN is powerful and can play a leading role in combating piracy, ${ }^{157}$ because it has modern, fully equipped frigates and the MRS, which can be adapted to anti-piracy operations. ${ }^{158}$

However, to deal with piracy and other maritime challenges effectively, a political will is a prerequisite. ${ }^{159}$ For a number of years following the upsurge of piracy off the Horn of Africa, South Africa made no commitments to anti-piracy operations. The SAN declared its readiness to embark on anti-piracy operations; however, only the president and Parliament could make the final decision. By implication, no political will prior to 2011 emanated from government pertaining to ways to deal with piracy. Nonetheless, the SAN admitted its readiness to deploy whenever needed and has always sent its members on special courses and missions to acquire more knowledge on piracy. In 2010, for instance, the European Union Naval Force (EU NAVFOR) in Somalia offered the SAN an opportunity to deploy officers as observers to some of their operations. ${ }^{160}$ Consequently, Lieutenant Commander M. Morgan (operations officer on board SAS Mendi) and Lieutenant (SAN) S.M. Matabane (then second in 
charge of the OBD, and now RFD commander at the MRS) ${ }^{161}$ from the SAN as well as Lieutenant M.P. Mosoeunyane from 4 Special Forces were attached as observers to HNLMS Johan de Witt - a Dutch landing platform dock. Their deployment commenced on 28 May and lasted until 29 July 2010 and provided them with invaluable experience and information in the planning and execution of anti-piracy operations. ${ }^{162}$ The three officers also observed the planning and execution of anti-piracy operations.

In January 2011, two cases of piracy off the Southern African coastline were confirmed. The first was a Taiwanese fishing trawler that went missing on 25 December 2010 northeast of Madagascar, and the second was a Mozambican fishing trawler that was reported missing between Mozambique and Madagascar. The latter was spotted towed by pirates towards the Comoros. In addition, there were confirmed cases of attempted piracy on ships in the vicinity of Beira port in Mozambique in December 2010. One of the reasons for piracy in Southern African waters is the geography of the coastline. The Mozambique Channel is attractive to pirates because it forms a natural corridor separating Mozambique and Madagascar and reduces the manoeuvrability of vessels, making them vulnerable to attacks. The maritime traffic in the area is also dominated by unarmed vessels and is an alternative route for cargo and other commercial vessels avoiding the route near the Horn of Africa. ${ }^{163}$ The absence, at that time, of anti-piracy patrol forces also made the region more attractive to pirates because countries in the region, with the exception of South Africa, lack naval assets to patrol the waters. Since 2008, the Horn of Africa, on the other hand, is patrolled by naval deterrence forces from states such as Canada, Denmark, France, India, the Netherlands, Russia, Spain, the United Kingdom and the United States. In December 2008, the European Union commissioned Operation Atalanta, a naval operation to deter piracy and related activities off the coast of Somalia. ${ }^{164}$ Other operations include those conducted by the USA's Combined Task Force 151, NATO's Operation Ocean Shield and other navies. ${ }^{165}$

Since 2011, the situation with regard to political will has significantly changed in Southern Africa. During a SADC defence meeting aimed at developing an anti-piracy strategy in July 2011, Minister Sisulu admitted that piracy was becoming a major concern for Southern Africa. She added that military strategists were devising options to deal with piracy. ${ }^{166}$ 
Witnessing the propensity that piracy seemed to be moving towards Southern Africa, Parliament, after requests from Mozambique and Tanzania, approved naval patrols along the Mozambique Channel and off the coast of Tanzania to deter piracy commencing in early 2011. These patrols are carried out under Operation Copper (discussed later). To intensify antipiracy efforts, ministers of defence of South Africa, Mozambique and Tanzania have signed a trilateral memorandum of understanding (MoU) on maritime security cooperation in February 2012. The aim of the MoU is to eliminate piracy and to ensure security and the safety of the East African coast from Tanzania and Mozambique to South Africa. At the signing of the MoU, President Jokaya Kikwete of Tanzania expressed his appreciation to President Zuma of South Africa and President Armando Guebuza of Mozambique for joining hands in fighting piracy in Southern African waters. ${ }^{167}$ The MoU illustrates the seriousness of piracy and the political will to fight the phenomenon. Whether anti-piracy operations can be sustained for a longer period and ultimately lead to the safety and security in Southern African waters remain to be seen. Currently, however, anti-piracy operations are continuing under Operation Copper.

\section{Operation Copper: Anti-Piracy Operations off the Southern African Coast}

Operation Copper is an anti-piracy operation off the coast of Mozambique and Tanzania that began in early 2011 following the call for South Africa to begin playing a meaningful role in eradicating piracy at sea. ${ }^{168}$ The operation may be comprehended within the ambit of South African naval diplomacy, which is defined as the use of maritime coercion, naval cooperation, international maritime assistance and international conflict resolution and management to support foreign policy objectives. ${ }^{169}$ Maritime coercion, naval cooperation, international maritime assistance and international conflict resolution and management are four functions of South African naval diplomacy informed by SANGP 100 clarifying the traditional roles of the SAN, namely the diplomatic, military and policing roles, as well as various theories of naval diplomacy by authors such as Geoffrey Till, James Cable, Kenneth Booth, Edward Luttwak and Alfred Mahan. ${ }^{170}$

Maritime coercion is a province of Cable's gunboat diplomacy, which is defined as the use of limited naval force including definitive force, 
purposeful force, catalytic force and expressive force in support of foreign policy objectives. ${ }^{171}$ Maritime coercion consists of two subsets: maritime deterrence and compellence. The former refers to an action pursued to influence the other party to refrain from certain actions by creating a belief that the ends of such actions will outweigh the means, whereas the latter is an action taken to create awareness that the outcome of an action or lack of action by an actor may have grievous consequences. ${ }^{172}$ Operation Copper may be understood as a maritime deterrence operation by the SAN to support the ends of the country's policy. After all, Operation Copper is conducted in the waters of Mozambique and Tanzania, following a formal request, which makes it part of South African naval diplomacy.

The hijacking of the Vega 5, a Spanish fishing trawler, in the Mozambique Channel on 28 December 2010 sparked the operation. Mozambican authorities requested assistance from South Africa and the government responded by authorising naval deployments to the Mozambique Channel. ${ }^{173}$ Operation Copper is the SAN's first standing commitment since the end of the Second World War. ${ }^{174}$ Although many operations of some elements of the SANDF remain classified, other information is released to the media. Very limited information, however, is released to the public with regard to this operation due to issues relating to security. Hence, the exact nature of the anti-piracy operations' assets composed of the MRS and the special forces on board the SAN vessels during the operation is highly classified. The first deployment for Operation Copper occurred in February 2011 when SAS Mendi - commanded by Captain (SAN) J. Schutte with the members of the MRS and special forces on board - was deployed to the Mozambique Channel on anti-piracy operations. ${ }^{175}$ During the deployment, SAS Mendi conducted anti-piracy patrol in Mozambique Channel and off the coast of Tanzania. Five officers from the Mozambican Navy deployed with the ship for the duration of the deployment. ${ }^{176}$ President Zuma informed Parliament that he extended the "the employment of the [SANDF] for service in Mozambique waters and in international waters to monitor and deter piracy activities along the Southern African Coast of the Indian Ocean”. ${ }^{177}$ SAS Mendi returned on 19 May 2011 from the first deployment, which took 115 days. ${ }^{178}$

SAS Amatola conducted a four-month-long second deployment for Operation Copper, which ended on 19 September 2011. ${ }^{179}$ Concurrently, as 
SAS Amatola returned from anti-piracy patrol, SAS Mendi headed for Pemba to take her second anti-piracy patrols for the operation. ${ }^{180}$ The other two frigates, SAS Isandlwana and SAS Spioenkop, have also been involved in the operation. At any time since the beginning of the operation early in 2011, one of the four frigates is conducting anti-piracy operations off Mozambique Channel and off the coast of Tanzania. ${ }^{181}$ SAS Drakensberg is also involved in the patrols following the absence of frigates as they were undergoing scheduled repair and maintenance. The MRS has been involved in Operation Copper since its commencement. The teams serve on board frigates during anti-piracy patrols, ${ }^{182}$ and it can be argued that they are instrumental in fighting piracy during the operation, as they are the antipiracy assets on board the ships. These teams are responsible for boarding operations as one of their main roles. According to Lieutenant (SAN) F.M. Rossouw, Operation Copper's boarding officer in two rotations, there are two types of operations, namely compliant and non-compliant boarding. ${ }^{183}$ The former is conducted when the vessels in question give their consent for the MRS to board, and the latter involves vessels refusing to comply with boarding requests. During compliant boarding, the crew of the vessels are informed of the requirements. For instance, fishing vessels are required to have all their permits in a central place such as the bridge. Cargo vessels that have private security personnel to protect themselves against pirates are advised to store away all weapons on board. ${ }^{184}$

Non-compliant boarding operations entail vessels, particularly fishing vessels, which refuse granting access to the MRS to conduct search operations on board. These types of operations are divided into two subgroups, namely opposed and unopposed boarding operations. ${ }^{185}$ Opposed non-compliant boarding operations include a threat of use of force as members board the ships with weapons ready to return fire if attacked. These are dangerous operations, which may often be performed under fire from the opposing forces. Unopposed non-compliant boarding operations do not necessary include the threat of force. They may be a consequence of lack or failure of communication between the MRS and the crew of the vessels due to technical failures. When members board the vessels during these operations, they are unopposed by the crews on board. The MRS has conducted unopposed non-compliant operations during Operation Copper. The crew of vessels, fishing vessels in particular, often cite the issue of time as the reason for their refusal. Time is of the essence for fishing trawlers, 
and inspection of a vessel implies that the crew has to stop its duties for the duration of the boarding operation. Nonetheless, boarding operations are conducted as long as the vessel is deemed suspicious.

Suspicious vessels include those not responding to radio contact and those identified by intelligence services as having connections to piracy and other illicit activities. Since the beginning of Operation Copper, there have been more than two rotations of members of the MRS responsible for boarding. ${ }^{186}$ It was during a boarding operation that the MRS lost one of its members, Able Seaman T.E. Mbuli, on 23 May 2012. While conducting a boarding operation on the Iranian dhow Hoane, a vessel of interest during the operation, Mbuli lost his footing and fell into the sea during the disembarkation. ${ }^{187}$ Boarding operations are some of the dangerous tasks, which the MRS conducts in Operation Copper. In case they intercept a pirate vessel, it should be noted that most pirates off the coast of Somalia are armed with AK-47s, handguns and RPGs. The IMB states that Somali pirates are armed and dangerous, and do not hesitate to fire at ships using AK-47s and RPGs in order to force such ships to come to a halt. ${ }^{188}$ The 68 crew members of MT Irene $S L$, a supertanker hijacked by Somali pirates in February 2011 can attest to the ferocity of Somali pirates. The crew spent 58 days in captivity prior to their release in April 2011 and recalled the traumatic experiences they underwent amidst their captors armed with the cited weapons. ${ }^{189}$ Regardless of the danger and other challenges facing the MRS, its members continue to play a role in Operation Copper.

In April 2012, more than a year since the commencement of Operation Copper, the impact of the MRS in anti-piracy was realised during a multinational anti-piracy operation including SAS Drakensberg, Tanzanian forces and the European Union forces. The operation followed an unsuccessful pirate attack on a Filipino merchant vessel in the Mozambique Channel. Concurrently, the Maritime Rescue and Coordination Centre in Tanzania issued a safety warning regarding the Dandelion, a South Africanowned yacht en route from the French island of Mayotte to Pemba in Mozambique. ${ }^{190}$ On Sunday 15 April 2012, the French Navy responsible for patrolling the area requested assistance from the SANDF with regard to search efforts. Being at the right place at the right time, SAS Drakensberg with the MRS on board commenced searching for the Dandelion. When the yacht was spotted off the coast of Pemba on Monday morning, 16 April 
2012, the pirate mother ship was also identified as Nimesha Duwa, a Sri Lankan fishing trawler captured by pirates in November 2011. The search and rescue mission was then transformed into piracy interdiction operation and SAS Drakensberg was responsible for forcing the Nimesha Duwa to escape to the north of the Mozambique Channel towards Tanzanian and European Union forces. ${ }^{191}$ By the afternoon of Wednesday, 18 April, the pirates had felt the pressure of hot pursuit and decided to split up, leading to five of them being located and arrested on Songo Songo Island by the Tanzanian authorities. In the evening, SAS Drakensberg and the Tanzanian and European forces closed in on the pirates' mother ship and the Spanish ship captured the vessel at 20:30 military time. Seven pirates were arrested and six hostages of the Sri Lankan fishing trawler rescued.

Despite the recent success in Operation Copper, it should be noted that the MRS faces certain challenges. Firstly, unlike marines of developed states such as the USA, which have documents such as the USMC Small Wars Manual and the Marine Corps Manual outlining training, initial operations, logistics, infantry patrols, mounted detachments, river operations as well as withdrawal of marines, ${ }^{192}$ the MRS lacks an updated doctrine. Secondly, the new $\mathrm{CoO}$ of the MRS has not yet been approved, making it difficult for members to inculcate defined standard operating procedures for boarding operations for all elements participating in Operation Copper, such as the SAAF. ${ }^{193}$ Currently, the MRS is using the old doctrine inconsistent with the current challenges such as piracy. Subsequently, the members have to explain to the officers commanding various ships and elements of the $\mathrm{SAAF}$ with regard to boarding procedures. It should be expressed that the sooner the new $\mathrm{CoO}$ is approved the sooner this challenge can be resolved. Based on the fact that most of the Southern African trade is conducted via the sea, it seems that Operation Copper will likely continue for many years to come and the MRS officers should be empowered with all the resources, including doctrines and $\mathrm{CoO}$ reflecting the current challenges.

Conducting anti-piracy operations shows South Africa's commitment towards maritime security in African waters. Some analysts, however, such as Heitman, believe that deployment to the Mozambique Channel should have commenced ages ago because piracy is threatening South Africa's commercial interests. ${ }^{194}$ It should be considered that combating piracy off The East African coast is not the sole responsibility of South Africa. 
Although most states in the region lack naval assets, they are also responsible for resolving the situation and deterring piracy. There are two pertinent questions regarding anti-piracy operations in the South African case. Firstly, is South Africa capable of conducting such anti-piracy operations at a greater scale or not? Secondly, has Operation Copper, from its commencement in 2011 to 2012, been successful or not?

The answer to the first question may be attributed to resources. The defence budget cuts are limiting the SAN's operational capabilities. Government reduced the sea-going hours to 8000 for 2011 and 2012, from 9000 in 2010. Given this reality, the SAN can only afford to deploy one frigate and, perhaps a support vessel, on each rotation for Operation Copper. The four frigates and SAS Drakensberg rotate deployment to the Mozambique Channel. Engaging in anti-piracy operations off the coast of Somalia seems to be unproductive for the SAN given the fact that approximately 30 other foreign naval vessels are engaged in anti-piracy operations in the area. Thus, it is justifiable for the SAN to concentrate its operations in SADC waters to avoid overstretching its capabilities. ${ }^{195}$ Failure to concentrate on SADC waters may not only result in an inability to perform the primary and secondary functions of the SAN as provided in the Constitution, but also Operation Copper. In attempting to answer the second question, the success of Operation Copper and the contribution of the MRS should not be judged by the number of pirates apprehended. In fact, the MRS has not yet apprehended any pirates except contributing to those apprehended in April 2012 as cited. The successes, however, should be judged by the fact that suspicious activities in the Mozambique Channel and off the coast of Tanzania have decreased in the past two years.

Various sources have reported a plunge in piracy off the East African coast in the recent past. The 2011 Annual Report of the IMB states that the number of successful hijackings by Somali pirates has decreased from 49 in 2010 to 28 in 2011. ${ }^{196}$ As reported by The New York Times, statistics released by the US Navy revealed that only nine pirate attacks have been successful this year compared to 34 in 2011 and 68 in 2010. ${ }^{197}$ Regardless of the inconsistencies in 2010 and 2011 numbers, the trend is that piracy around Somalia has declined. This decline can be credited to aggressive anti-piracy patrols by international navies operating in the area as well as measures taken by commercial shipping companies such as employing 
private security personnel on board ships. ${ }^{198}$ The fact that no vessel has been hijacked since Operation Copper commenced in the Mozambique Channel and the Tanzania coast illustrates the success of the operation. Although there are reports of piracy descending from the Horn of Africa towards Southern Africa, as indicated by Minister Sisulu and Vice-Admiral Mudimu during IONS 2012, ${ }^{199}$ the region has not yet experienced major challenges. Subsequently, it may be argued that the SAN in general, and the MRS and the elements of special forces in particular, together with other elements involved in the operation have successfully conducted maritime deterrence in the region. Without naval anti-piracy patrols, the region would be experiencing piracy as illustrated by the cited piracy cases.

\section{Conclusion}

In order to possess a marine capability, South Africa established three sets of marines during different periods since the formation of the UDF in 1912. South Africa, however, lacks an unbroken history of an organisation that developed over time. The three different marines were created for various reasons specific to the time of their creation. The aim of this article was to analyse the MRS as the resurrected marine capability of the SAN. The reasons for the creation of the MRS were articulated in the article. In addition, the roles and functions of the MRS have been dealt with. Undoubtedly, the MRS symbolises the resurrected marine capability created to enable the SAN to contribute meaningfully to South Africa's involvement in peace missions. Although Project Xena has equipped the MRS with the boat system as well as the FDB, the unit still faces several challenges including the lack of strategic sealift capability and proper equipment for boarding operations. In addition, the current equipment is either aged or is ageing.

Its revised and updated $\mathrm{CoO}$ is yet to be approved. Regardless of these challenges, the MRS has participated in naval and other exercises such as Shared Accord, Golfinho, Good Hope, and Ndlovu in which it played multidimensional roles from beach-landing to anti-piracy demonstrations. In order to contribute to international conflict resolution and management as part of South African naval diplomacy, the MRS deployed elements to the Great Lakes region to perform boat operations in Lake Kivu and Tanganyika, guarding duties in Burundi and aviation protection duties in the 
DRC. Internally, the MRS has provided maritime and naval deterrence in the coastal host cities of Durban, Port Elizabeth and Cape Town during Operation Kgwele in 2010.

As part of maritime and naval cooperation with other navies in the region, South Africa entered into a MoU with Tanzania and Mozambique aimed at eradicating piracy and other sources of maritime insecurity in Southern Africa. The MoU strengthens Operation Copper in which the MRS has been continuously involved since 2011. This operation is part of the maritime and naval coercion domain of South African naval diplomacy. The RFD conducts compliant and non-compliant boarding operations, which include opposed and unopposed boarding during the deployment on board suspicious vessels. Although the MRS has not yet apprehended pirates, it assisted other forces during the recent arrests of pirates by Tanzanian authorities. The operation seems to have served as deterrence for pirates in the region as demonstrated by the plunge in reported attempted and actual pirate hijackings. Based on the findings, the MRS is indeed the resurrected marine capability for the SAN.

To ensure that the MRS continues to be the marine capability, it is recommended that the SAN should resolve the challenges faced by the unit. The equipment (for example suitable boats) of the members should be conducive to the amphibious environment; fast-roping equipment for boarding operations should always be serviceable and reliable because the members' lives depend on it; the ageing diving boats for the ODD should be replaced; and sealift capability is a necessity for the unit to deploy with the FDB to distant regions. Failure to address most of these challenges will result in the resurrected marine capability being reduced to nothing but a force for ceremonial purposes. The success of the MRS depends largely on the support of the SAN, the SANDF and government.

Unlike the previous two marines that lasted 5 and 10 years respectively, it seems the MRS would likely survive for a very long period because there are no indications that the recent missions such as anti-piracy and peace missions will end in the near future. Hence, support from all stakeholders is of importance for the MRS to survive. The creation of three types of marines during different periods indicates that South Africa and the SAN have always wanted a marine capability, but the will to provide the 
necessities institutionally, such as adequate funding, to ensure the success of the force, seemed to be lacking. For the MRS to survive and be successful, it is necessary to take serious cognisance of what is required to make it work.

1 US Marine Corps. Amphibious operations in the $21^{\text {st }}$ century. Washington, DC: US Marine Corps, 2009, 5-6.

2 Ibid.

3 Ibid., p. 14.

4 South African Navy. SANGP100. Simon's Town: SA Navy Publications Unit, 2006, 57-58.

5 See PL Moorcraft. Africa's super power, Johannesburg: Sygma and Collins, 1981, 128; WA Dorning. "A concise history of the South African Defence Force (1912-1987)”, Scientia Militaria: South African Journal of Military Studies 27/2. 1987. 17. C Bennett. South African naval events day-by-day 1488 to 2009. Simon's Town: Naval Heritage Trust, 2011, 92.

7 D Fourie. “The South African corps of marines”. Military History Journal 1/1. 1967. 3.

$8 \quad$ Dorning op. cit.

$9 \quad$ Bennett op. cit., p. 92.

$10 \mathrm{R}$ Southall. "Africa in the contemporary world". In PJ McGowan, S Cornelissen \& P Nel (eds), Power, wealth and global equity: An international relations textbook for Africa, Cape Town: UCT Press, 2006, 225. For more information on the Border War, see W Steenkamp. "The citizen soldier in the Border War”. Journal for Contemporary History 31/3. 2006. 912; CJ Jacobs. "The forward defence strategy of the South African Defence Force (SADF), 1978-1989”. Journal for Contemporary History 31/3. 2006. 23; J Pearce. An outbreak of peace: Angola's situation of confusion. Claremont: David Philip Publishers, 2005, 2; Moorcraft op. cit., pp. 34-41; J Hanlon. Mozambique: The revolution under fire. London: Zed Books, 1984, 24.

12 IC Little. Above board and under cover. Durban: Just Done Productions Publishing, 2009, 108.

$13 \quad$ Moorcraft op. cit., p. 128.

14 H Heitman. "Born of necessity: South Africa's post-apartheid Navy finds efficiency is the route to survival”. Jane's Navy International 100/5. 1995. 84.

15 Ibid., p. 87.

$16 \quad$ Little op. cit., p. 109.

$17 \quad$ Ibid., p. 125.

18 For more information, see CH Bennett \& AG Söderlund. South Africa's Navy. Simon's Town: SA Navy, 2008, 43.

$19 \quad$ Heitman op. cit., p. 88.

$20 \quad$ Bennett \& Söderlund op. cit., p.145. 
21 ACCORD. "South Africa's peacekeeping role in Burundi: Challenges and opportunities for future peace missions”. Occasional Papers Series 2/2. 2007. 21.

22 G Matheba. The role of South Africa in the security structures of southern Africa. Pretoria: Department of International Relations and Trade, 2003, 15; and Department of Foreign Affairs. White Paper on South African Participation in International Peace Missions. Pretoria: Department of Foreign Affairs, 1999, 3. See A Habib. "South Africa's foreign policy: Hegemonic aspirations, neoliberal orientations and global transformation”. South African Journal of International Affairs 16/2. 2009. 148; and M Lipton. "Understanding South Africa's foreign policy: The perplexing case of Zimbabwe”. South African Journal of International Affairs 16/3. 2009. 334. For more information, see H Solomon. "South Africa in Africa: A case of high expectations for peace". South African Journal of International Affairs 17/2. 2010. 134; and A Vines. "South Africa's politics of peace and security in Africa”. South African Journal of International Affairs 17/1. 2010. 59.

Matheba op. cit., p. 20.

CH Ross. "Maritime peacekeeping: A look at the last decade". Navy News 22/1. 2003. 24.

For more information, see Bennett op. cit., pp. 61-62; T Mbeki. "Address by the then President of South Africa and Commander-in-Chief of the SANDF, Thabo Mbeki". Navy News 27/5. 2008. 30; and H Werkman. "A President for world peace”. Navy News 18/5. 1999. 15.

Public Relations Department. "Statement by SA National Defence Force (SANDF) Headquarters Pretoria: Statement by SA Navy commissions new specialist military unit”. Media Statements. 8 December 2008. Naval Base Simon's Town: Public Relations Department.

H Heitman. "Crises response capability: A role for South Africa”. African Security Review 11/1. 2002. 67. J Sverdloff. "For the sake of democracy". Navy News 24/4. 2005. 20-21.

"Chief of the Navy in conversation, Part One". Navy News 24/4. 10. Executive Officer MRS and currently staffed at Fleet Force Preparation, 27 September 2012. Public Relations Department op. cit. P Janse van Rensburg. "Lean, mean fighting machine”. Navy News 28/1. 2009. 27. Author's interview with Captain (SAN) SA Malepe, Officer Commanding MRS, 19 March 2012, MRS Headquarters, Scala. Janse van Rensburg op. cit. Bennett \& Söderlund op. cit., p. 145. Author's telephonic interview with Commander Combrink op. cit. Author's interview with Captain (SAN) Malepe op. cit. 
Author's reminiscence during interviews with relevant naval officers.

Department of Defence. Strategic Business Plan 2009. Pretoria: Department of Defence, 2009, 61.

Bennett \& Söderlund op. cit., p. 146.

Author's interview with Captain (SAN) Malepe op. cit.

M Gounden. "Media gained valuable insight into our Navy". South African Soldier 10/11. 2003. 10.

Janse van Rensburg op. cit.

Author's interview with Captain (SAN) Malepe op. cit.

Bennett \& Söderlund op cit.

South African Navy, op. cit., p. 57.

See "PIEDS-LOURDS”. Navy News 17/4. 1998. 16-17.

Bennett \& Söderlund op. cit., p. 145.

Ibid.

Ibid., p. 146.

Author's telephonic interview with WO2 I du Plessis, MRS ODD, 7 July 2012. Also see B du Plessis. “Hey-Ho King Neptune”. Navy News 25/5. 2006. 26-29.

D Oosthuizen. “The Navy helps solve the puzzle”. Navy News 29/6. 20-21.

Author's telephonic interview with WO2 Du Plessis op. cit.

Ooshuizen op. cit.

“Dozens killed in Zanzibar ferry disaster”. Al Jazeera. 19 July 2012. $<$ http://m.aljazeera.com/SE/201271814217312822> Accessed on 20 July 2012.

"SA divers help in Tanzania boat disaster”. SABC News. 12 September 2011. <http://www.sabc.co.za/news/a/2b6f1200484e2d7f89848bbc377775ee/SAdivers-help-in-Tanzania-boat-disaster-20110912> Accessed on 10 April 2012. Janse van Rensburg op. cit.

K Kalake. "MRS selection: Survival of the fittest”. Navy News 29/3. 2010. 8. Author's telephonic interview with Commander Combrink op cit.

G Harman. “Ops INTEXO hitting poaching where it hurts”. Navy News 26/4. 2007. 10.

Author's interview with Captain (SAN) Malepe op. cit.

P Janse van Rensburg \& K Stone. "Teeth and tail: The Maritime Reaction Squadron's nice new kit”. Navy News 28/2. 2009. 12.

Department of Defence. Department of Defence Annual Report FY 2009/10. Pretoria: Department of Defence, 2010, 60.

Author's anonymous interviews with members of the MRS on various dates during 2011 and 2012.

Author's interview with Captain (SAN) Malepe op. cit.

Public Relations Department op. cit.

Janse van Rensburg op. cit.

L Engelbrecht. "Xena Xplained”. defenceWeb. December 2008. <http://www.defenceweb.co.za/index.php?option=com_content\&task=view\&i $\underline{\mathrm{d}=892 \& \text { Itemid=363 }}>$ Accessed on 12 June 2011.

L Engelbrecht. "Exercise Xena testing Maritime Reaction Squadron”. defenceWeb. 
<file:///H:/Academic/publication\%20information/Exercise\%20Xena\%20testin g\%20Maritime\%20Reaction\%20Squadron\%20\%20\%20DefenceWeb.htm> Accessed on 12 June 2011.

D Maleka. "The Maritime Reaction Squadron reveals its Forward Deployable Base”. South African Soldier 17/3. 2010. 28.

Ibid., p. 29.

D Wingrin. "Exercise Xena testing Maritime Reaction Squadron". defenceWeb. $26 \quad$ November 2009. $<$ http://www.defenceweb.co.za/index.php?option=com content\&view=article \&id=5544\&catid=51:Sea\&Itemid=106 $>$ Accessed on 20 January 2010.

Maleka op. cit., p. 29.

For more information see "South African Navy to meet African conflicts". African Armed Forces Journal March 2007; H Heitman. "African navies and peacekeeping: A role for South African Navy”. In T Potgieter \& R Pommerin (eds.), Maritime security in southern African waters, Stellenbosch: Sun Media, 2009.

It transpired during one of the author's anonymous interviews.

K Booth. Navies and foreign policy. London: Croom Helm, 1977, 18.

G Till. Seapower: A guide for the twenty-first century. London: Routledge, 2009, 287.

Author's interview with Captain (SAN) PJ Eldon, Senior Staff Officer Maritime Strategy, 13 July 2012, Navy Headquarters, Pretoria.

S McCarthy. Exercises and training: The key to developing security cooperation under the new US Africa Command. Newport, RI: Naval War College, 2007, 12.

E Saenz. "American forces arrive at Niger for Shared Accord”. United States European Command. $10 \quad$ March 2006. $<$ http://www.eucom.mil/article/21306/American-forces-arrive-Niger-SharedAccord-06> Accessed on 13 January 2011.

DE Preston. "Service members bring training, humanitarian aid to Senegal". United States European Command. 26 June 2007. <http://www.eucom.mil/article/20862/service-members-bring-traininghumanitarian-aid > Accessed on 23 January 2012.

DE Preston. "Thousands of Ghanaians benefit from Shared Accord humanitarian relief”. 25 June 2008. Unites States Africa Command. 26 June 2008. < http://www.africom.mil/getArticle.asp?art=1843> Accessed on 23 January 2012.

J Sleiman. "Marines mentor Mozambican soldiers during Shared Accord 2010 live fire course". Marines, the few, the proud. 6 August 2010. <http://www.marines.mil/unit/marforaf/Pages/MarinesmentorMozamb icansoldiersduringSHAREDACCORD2010livefirecourse.aspx\#.UBZP1mFa $\underline{4 \mathrm{dM}}>$ Accessed on 12 May 2010.

C Szabo. "US marines land in South Africa for Exercise Shared Accord".

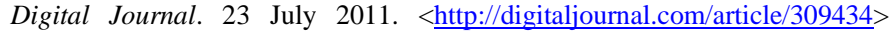
Accessed on 12 April 2012. 
J Theunissen. South African National Defence Force (SANDF) and United States Armed Forces to conduct humanitarian exercise in Port Elizabeth. Statement by the Department of Defence, 24 June 2011.

Author's telephonic interview with Lieutenant (SAN) FM Rossouw, Company Second in Charge at the MRS, 25 September 2012.

US AFRICOM Public Affairs. "Parade marks end of Exercise Shared Accord 2011”. US Africa Command. 5 August 2011. $<\underline{\text { http://www.africom.mil/getArticle.asp?art }=7047 \text { \&lang }=0}>$ Accessed on 10 September 2011.

D Williams. "Exercise Golfinho (Sitrep 05): A glimpse of Exercise Golfinho”. South African Navy. 23 September 2009.

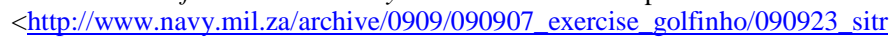
ep_05/article.htm> Accessed on 21 June 2011.

Defence Corporate Communication. Department of Defence briefing on Exercise Golfinho. Department of Defence Media Invitation, 17 August 2009, 1.

Williams op. cit.

A Rakoma. "The People’s Navy showing its might”. South African Soldier 17/4. 2010. 14.

H Boshoff. "Exercise Golfinho an example for other Continental Brigades". defenceWeb. $13 \quad$ October 2009. $<$ http://www.iss.co.za/iss_today.php?ID=1110> Accessed on 20 June 2011. S Khasuli. "Exercise Golfinho (Sitrep 02): History in the making”. South $\begin{array}{lllll}\text { African } & \text { Navy. } & 7 & \text { September } & \end{array}$ <http://www.navy.mil.za/archive/0909/090907_exercise_golfinho/090907_sitr ep_01/article.htm> Accessed on 20 June 2011.

Author's telephonic interview with Commander Combrink op cit.

See S Khasuli. "Exercise Golfinho (Sitrep 02): Forces participating in Walvis Bay”. South African Navy. 7 September 2009. <http://www.navy.mil.za/archive/0909/090907_exercise_golfinho/090907_sitr ep\%C2\%AD 02/article.htm> Accessed on 20 June 2011; K Stone. "Exercise Golfinho”. Navy News 28/5. 2009. 16-19.

B Linganiso. "SAS Simonsberg and the Maritime Reaction Squadron”. Navy News 27/1. 2008. 11.

Khasuli, "Exercise Golfinho (Sitrep 02): Forces participating ...” op. cit. Stone op. cit., p. 19.

See Bennett op. cit., p. 25; B du Plessis. "Exercise GOOD HOPE II”. Navy News 25/2. 2006. 28-31.

ND Herne \& JG Grant. “Exercise GOOD HOPE 3”. Navy News 28/2. 2008. 18.

N Herne. "Exercise GOOD HOPE IV”. Navy News 29/1. 2010. 16-20.

Rakoma op. cit., p. 15.

A Rakoma. "Exercise GOOD HOPE V concludes". Department of Defence. $27 \quad$ March 2012. <http://www.dod.mil.za/news/news2012/march/goodhope5.htm $>$ Accessed on 23 April 2012. 
Public Relations Department. Exercise Good Hope V. Media Release. 30 March 2012. Naval Base Simon's Town: Public Relations Department.

Department of Defence. "Exercise NDLOVU 11". Department of Defence. 20 November 2011. <http://www.dod.mil.za/news/news\%202011/November11/Exercise_Ndlovu.h tm> Accessed on 23 April 2012.

J Baatjies. "Exercise NDLOVU”. Navy News 31/1. 2012. 12. Author's own experience, 7 November 2011, Saldanha Bay. Author's own experience op. cit. Author's interview with Rear-Admiral (Junior Grade) DJ Christian, Director Naval Logistics, 10 July 2012, Navy Headquarters, Pretoria.

K Lautenschläger. "The submarine in naval warfare, 1901-2001". In SE Miller \& S van Evera (eds), Naval strategy and national security: An international security reader, NJ: Princeton University Press, 1988, 241.

Baatjies op. cit.

Author's telephonic interview with Commander Combrink op cit.

Department of Defence. Strategic Business Plan 2008. Pretoria: Department of Defence, 2008, 40.

Author's interview with Sub-lieutenant DS Thukani, member of the MRS studying at the Military Academy, 26 September 2012, Military Academy, Saldanha.

Department of Defence. Strategic Business Plan 2008 op. cit.

Author's telephonic interview with Commander Combrink op cit.

Author's anonymous interview with members of the MRS.

Author's anonymous interview with members of the MRS.

During the author's interview with Captain (SAN) Malepe op cit, it transpired that the leadership element of the MRS receives infantry training at the Infantry School as well as amphibious training in the SAN. These members function in both the land and amphibious environments.

I Cloete. "R Adm (JG) MS Hlogwane and Captain SF Peterson pay a visit to our deployed sailors in the DRC”. South African Navy. 27 May 2009. <http://www.navy.mil.za/archive/0905/090527_DRC_visit/article.htm>

Accessed on 12 June 2011.

K Kalake. "Farewell for MRS members deploying to the DRC". South African Navy. $18 \quad$ May 2009. < $\underline{\text { http://www.navy.mil.za/archive/0905/090518_MRS_deploys_to_DRC/articl }}$ e.htm> Accessed on 17 June 2012.

Author's telephonic interview with Sub-lieutenant RO Letsoalo, Platoon Commander in the MRS who deployed to the DRC, 26 September 2012.

S Chengan. "Maritime Reaction Squadron welcomes home members from deployment”. South African Navy. 17 June 2011. <http://www.navy.mil.za/archive/1106/110617 members from deployment/a rticle.htm> Accessed on 23 May 2012.

Author's anonymous interview with members deployed to the DRC under Operation Mistral.

D Oosthuizen. "Beyond Kgwele: Behind the scenes”. Navy News 29/3. 2010. $18-22$. 
131 A Rakoma. "Operation Kgwele: A legacy that transcends the glory of victory”. South African Soldier 17/8. 2010. 18. B Sibanyni \& I Makhubele. “Operation Kgwele: A success”. South African Soldier 17/7. 2010. 15.

B Sibanyoni. “A landmark occasion in our country's history”. South African Soldier 17/8. 2010. 14.

K Stone. "Operation Kgwele (Ball): SA Navy in support of the 2010 Soccer World Cup”. Navy News 29/1. 2010. 26.

Ibid.

VD Maleka. "SA Navy geared and ready for FIFA 2010 World Cup”. South African Soldier, 17/3. 2010. 27.

Kgwele is a Setswana word meaning "ball”, which reflected the 2010 FIFA World Cup. See Maleka op. cit., p.15.

See S Makuleni. "SA Navy safety and security: Ops Kgwele in coastal areas". South African Navy. 15 July 2010.2 http://www.navy.mil.za/archive/1007/100708_Operation_Kgwele/100715_saf ety security/article.htm> Accessed on 10 January 2011. Also see D Baker. "The South African Navy and African maritime security". Naval War College $\begin{array}{lll}\text { Review } & \text { 65/2. } & 2012 .\end{array}$ <http://www.navy.mil.za/archive/1007/100708_Operation_Kgwele/100715_sa fety_security/article.htm> Accessed on 12 January 2011. Baker op. cit., pp. 155-156.

Author's interview with Captain (SAN) A Kampfer, SAN Hydrographer, SAN Hydrographic Office, 21 February 2012, Silvermine, Tokai.

Stone, “Operation Kgwele (Ball) ...” op. cit., p. 26.

Makuleni op. cit.

Maleka, "SA Navy geared ..." op. cit., p. 27.

Makuleni op. cit.

Author's telephonic interview with Commander Combrink op cit.

ICC International Maritime Bureau. Piracy and Armed Robbery against Ships Annual Report, 1 January - 31 December 2007. London: ICC International Maritime Bureau, 2008, 3.

See J Gibson. "Maritime security and international law in Africa". African Security Review 18/3. 2009. 67; M Hough \& GPH Kruys (eds). Institute for Strategic Studies Ad Hoc Publication 4. University of Pretoria: ISS, 2009, 8586; United Nations. United Nations Convention on the Law of the Sea of 10 December 1982. New York: Division for Ocean Affairs and the Laws of the Sea, 1982, 60-61.

$\mathrm{T}$ Potgieter. "When maritime security is absent". In $\mathrm{T}$ Potgieter \& $\mathrm{R}$ Pommerin (eds), Maritime security in southern African waters, Stellenbosch: Sun Media, 2009, 9. M McNicholas. Maritime security: An introduction. Oxford: ButterworthHeinemann, 2008, 162-167.

See F Onuoha. "Sea piracy and maritime security in the Horn of Africa: The Somali coast and Gulf of Aden in perspective”. African Security Review 18/3. 2009. 31; G Swart. "Pirates of Africa’s Somali coast: On terrorism's brink?" Scientia Militaria: South African Journal of Military Studies. 37/2. 2009. 47. 
T Potgieter. "The maritime security quandary in the Horn of Africa region: Causes, consequences and responses”. East African Human Security Forum Discussion Paper. 2008. 5.

L Tlhaole. "Towards effective maritime governance for Africa”. South African Soldier 16/4. 2009. 14.

Heitman, "Born of necessity ...” op. cit., p. 40.

A Kruger. South Africa's frigates and the Somali pirates. The African.org. 10/11. 2010. 8.

See Onuoha op. cit.

Author was a delegate at the $3^{\text {rd }}$ Indian Ocean Naval Symposium, 10-13 April 2012, Cape Town International Convention Centre.

Author was a delegate at the $3^{\text {rd }}$ Indian Ocean Naval Symposium op. cit.

Kruger op. cit.

M Ncube \& ML Baker. "Beyond pirates and drugs: Unlocking Africa's maritime potential and economic development”. African Security Review 20/1. 2011. 67; OS Ibrahim. "To patrol is to control: Ensuring situational awareness in Africa's maritime exclusive economic zones”. African Security Review 18/3. 2009. 127.

B Mons. "Pirates of the $21^{\text {st }}$ century". Navy News 29/4. 2010. 30.

Author's interview with Lieutenant SM Matabane, OBD MRS, 19 March 2012, MRS Headquarters, Scala.

Mons op. cit.

B Coetzee. 2011. "Piracy in Southern Africa”. Institute for Security Studies. 14 January 2011. <http://www.issafrica.org/iss today.php?ID=1215> Accessed on 12 January 2012.

PV Rao. "Indian Ocean maritime security cooperation: The employment of navies and other maritime forces". Journal of the Indian Ocean Region 6/1. 2010. 131; European Union. European Security and Defence Policy. EU naval operation against piracy (EU NAVFOR Somalia: Operation Atalanta). Brussels: Consilium, 2009, 1.

Congressional Research Service. CRS Report for Congress: Prepared for Members and Committees of Congress. Washington, DC: Congressional Research Service, 2011.

"Sisulu: Piracy threat growing in Southern Africa”. Mail \& Guardian. 25 July 2011. <http://mg.co.za/article/2011-07-25-sisulu-piracy-threat-growing-insouthern-africa> Accessed on 20 June 2012.

Department of Defence. "Minister Sisulu signs a Memorandum of Understanding (MoU) on maritime security cooperation with Tanzania and Mozambique”. Department of Defence. 7 February 2012. <http://www.dod.mil.za/ministry/media_statements/2012/moutanzaniamozam bique.htm> Accessed on 12 September 2012.

Hough \& Kruys op. cit., pp. 92-97.

This is the author's working definition in a thesis on "South African naval diplomacy since 1994."

For more information on naval diplomacy theory, consult G Till. "The changing role of navies world-wide”. South African Defence Review 10. 1993; Till, Seapower ... op. cit.; Booth op. cit.; J Cable. Gunboat diplomacy: 
Political applications of limited naval force. London: Chatto and Windus, 1971; CS Gray. The leverage of sea power: The strategic advantage of navies in war. New York: The Free Press, 1992; E Luttwak. The political uses of sea power. Baltimore: Johns Hopkins University Press, 1975; AT Mahan. 1902. Retrospect and prospect. London: Sampson; AT Mahan. The life of Nelson. London: Sampson, 1899; AT Mahan. The interest of America in seapower: Present and future. London: Sampson, 1898; and AT Mahan. The influence of sea power upon history. London: Sampson, 1890.

Cable op cit., p. 21.

Till, Seapower ... op cit., p. 257.

G Murtin. "Southern Africa is safe - SA Navy Chief". defenceWeb. 23 February 2012.

$<$ http://www.defenceweb.co.za/index.php?option=com_content\&view=article \&id=23821: southern-africa-is-safe--sa-navychief\&catid=51:Sea\&Itemid=106 > Accessed on 13 June 2012.

S DeSilva-Ranasinghe. Interview: Vice Admiral Johannes Mudimu, Chief of the South African Navy. Jane's Defence Weekly. 18 July 2012.

Baker op. cit., p. 152.

G Walker. “Operation Copper”. Navy News 30/4. 2011. 24.

Parliament of the Republic of South Africa. Announcements, Tablings and Committee Reports. Cape Town: Parliament of the Republic of South Africa, 2011, 1.

Walker op. cit., p. 25.

J Baatjes. "A cheerful welcome of SAS Amatola”. Navy News 30/4. 2011. 23.

"Mendi on second Copper deployment". defenceWeb. 19 September 2011. $<$ http://www.defenceweb.co.za/index.php?option=com content\&view=article \&id=19183:mendi-on-second-copper-deployment-

\&catid=51:Sea\&Itemid=106> Accessed on 23 September 2011.

Author was a delegate at the $3^{\text {rd }}$ Indian Ocean Naval Symposium op. cit.

Baker op. cit.

Author's telephonic interview with Lieutenant (SAN) Rossouw op. cit. Author's telephonic interview with Lieutenant (SAN) Rossouw op. cit.

Author's telephonic interview with Lieutenant (SAN) Rossouw op. cit; Author's telephonic interview with Sub-lieutenant RO Letsoalo op. cit. Author's interview with Captain (SAN) Malepe op. cit.

NC Zulu. "A salute to a fallen SA Navy hero". South African Navy. 22 June 2012.

<http://www.navy.mil.za/archive/1206/120622_salute_to_a_hero/article.htm> Accessed on 25 June 2012.

ICC International Maritime Bureau. Piracy and Armed Robbery against Ships Annual Report, 1 January - 31 December 2011. London: ICC International Maritime Bureau, 2011, 22.

J Meyer \& H Fouché. "History in the making: SAPS and Interpol investigate piracy on the high seas”. Servamus June 2011. 8-11.

Daily News Correspondent. "SA Navy in Africa pirate bust". Daily News. 25 April 2012. < <http://www.iol.co.za/dailynews/news/sa-navy-in-africa-piratebust-1.1283505\#.UFnZSLIgeWl> Accessed on 25 April 2012. 
191

South African Navy. South African National Defence Force anti-piracy efforts pays dividends. Media Release. 25 April 2012.

The USMC has various manuals outlining organisation, functions and command, as well as other matters. For more information, see Department of the Navy. Marine Corps Manual. Washington, DC: Department of the Navy, 1980; and Department of the Navy. Small War Manual: United States Marine Corps. Washington, DC: Government Printing Office, 1940.

Anonymous interviews with members involved in Operation Copper.

G Hosken. "SA responds to piracy threat". Independent Online. 1 February 2011. $\quad<$ http://www.iol.co.za/news/africa/sa-responds-to-piracy-threat1.1019772\#.UBri2GE7XJg> Accessed on 14 June 2011.

A Kruger "The South African Navy facing up to reality”. Institute for Security Studies. $17 \quad$ February 2011.

http://www.issafrica.org/iss today.php?ID=1234>. Accessed on 14 June 2011. ICC International Maritime Bureau. Annual Report 1 January -31 December 2011 op. cit., p. 24.

T Shanker. "US reports that piracy off Africa has plunged". The New York Times. 28 August 2012. <http://www.nytimes.com/2012/08/29/world/africa/piracy-around-horn-ofafrica-has-plunged-us-says.html?_r=3> Accessed on 10 September 2012. Ibid.

Author was a delegate at the $3^{\text {rd }}$ Indian Ocean Naval Symposium op. cit. 